To the Editors:

\title{
A religious conversion
}

I was quite amused to read in recent $C M J$ article (1) that a person trained in a scientific discipline has been converted from one great faith to another just because of few situations that could have happened so commonly. By publishing this anecdotal article in your esteemed journal, I believe, you have have not served any purpose, but it is an insult to these two great religions as well as to the readers. I feel reducing the pages of the journal would be a better alternative than tarnishing it with such articles.

\section{Reference}

1. Basnayake V. A religious conversion. Ceylon Medical Journal 2001; 46: 138.

Dr H D B Herath (via email: hdbh@sltnet.lk).

\section{Correction}

In the paper titled "Antibodies to hepatitis $\mathrm{C}$ virus in patients who have had multiple transfusions in Sri Lanka" (CMJ, October 2001), the correct name of one author should have been S S D Fernando, and not S D D Fernando. 